\title{
Lung surfactant in a cystic fibrosis animal model: increased alveolar phospholipid pool size without altered composition and surface tension function in $c f t r^{\mathrm{m} 1 \mathrm{HGU} / \mathrm{m} 1 \mathrm{HGU}}$ mice
}

Wolfgang Bernhard, Jiu-Y Wang, Thomas Tschernig, Burkhard Tümmler, Hans J Hedrich, Horst von der Hardt

\begin{abstract}
Background-Progressive pulmonary dysfunction is a characteristic symptom of cystic fibrosis (CF) and is associated with functional impairment and biochemical alterations of surfactant phospholipids in the airways. However, the fundamental question of whether surfactant alterations in the CF lung are secondary to the pulmonary damage or are present before initiation of chronic infection and inflammation has yet to be resolved in patients with cystic fibrosis but can now be addressed in CF mice that exhibit the basic defect in the airways. A study was therefore undertaken to investigate the pool sizes, composition, and function of lung surfactant in the non-infected $c_{f t r}{ }^{\text {1HGU/m1HGU mouse. }}$

Methods - The amount and composition of phospholipid classes and phosphatidylcholine molecular species were determined in bronchoalveolar lavage (BAL) fluid and lavaged lungs by high performance liquid chromatography (HPLC). Surfactant protein A (SP-A) levels in BAL fluid were determined by ELISA and surfactant for functional measurements was isolated from BAL fluid by differential ultracentrifugation. Equilibrium and minimal surface tension of surfactant was assessed by the pulsating bubble surfactometer technique. MF1, BALB/c, C57/BL6, and $\mathrm{C} 3 \mathrm{H} / \mathrm{He}$ mice served as controls.
\end{abstract}

Results - BAL fluid of $c f t r^{\text {m1HGU/m1HGU }}$ mice contained 1.02 (95\% confidence interval (CI) 0.89 to 1.16$) \mu \mathrm{mol}$ phospholipid and 259 (239 to 279) ng SP-A. BAL fluid of $\mathrm{MF1}, \mathrm{BALB} / \mathrm{c}, \mathrm{C57BL} / 6$, and $\mathrm{C} 3 \mathrm{H} / \mathrm{He}$ mice contained 0.69 (0.63 to 0.75$), 0.50$ (0.42 to $0.57), 0.52(0.40$ to 0.64$)$, and $0.45(0.27$ to 0.63$) \mu \mathrm{mol}$ phospholipid, respectively. After correction for the different body weights of mouse strains, phospholipid levels in BAL fluid of $c_{t t}{ }^{\text {m1HGU/m1HGU }}$ mice were increased by 64 (52 to 76$) \%, 60$ (39 to $89) \%, 72$ (45 to 113$) \%$, and 92 (49 to 163$) \%$, respectively, compared with controls. The amount of SP-A in BAL fluid and the composition of phospholipid as well as phosphatidylcholine molecular species in BAL fluid and lung tissue was unchanged in $c f t r^{\mathrm{m} 1 \mathrm{HGU} / \mathrm{m} 1 \mathrm{HGU}}$ mice compared with con- trols. The increase in phospholipids in BAL fluid of $c f t r^{\mathrm{m} 1 \mathrm{HGU} / \mathrm{m} 1 \mathrm{HGU}}$ mice resulted from an increased fraction of large aggregates which exhibited normal surface tension function.

Conclusion - In cftr $^{\mathrm{m} 1 \mathrm{HGU} / \mathrm{m} 1 \mathrm{HGU}}$ mice surfactant homeostasis is perturbed by an increased phospholipid pool in the alveolar compartment.

(Thorax 1997;52:723-730)

Keywords: cystic fibrosis, surfactant pool size, cftrm ${ }^{m}$ HGU/miHGU mouse.

Cystic fibrosis is an inherited disease with a defect in the cystic fibrosis transmembrane conductance regulator $(C F T R)$ gene. This gene codes for an integrated plasma membrane protein which is responsible for cAMP regulated chloride transport through the plasma membrane. ${ }^{12}$ Mucus viscosity is increased in bronchial secretions from patients with cystic fibrosis. ${ }^{34}$ Additionally, airway surfactant from patients with cystic fibrosis chronically infected with Pseudomonas aeruginosa shows impaired function and altered phospholipid composition, possibly due to enzymatic destruction and contamination of surfactant secondary to infection. ${ }^{5}$ However, a primary alteration of surfactant metabolism in cystic fibrosis may additionally exist since the CFTR gene is expressed in Clara cells and type II pneumocytes. ${ }^{67}$ Type II pneumocytes synthesise and secrete all the phospholipid and apoprotein components of surfactant, while Clara cells release surfactant apoproteins SP-A, SP-B, and SP-D into the airways. ${ }^{89}$ Surfactant phospholipid comprises about $80 \%$ phosphatidylcholine (PC), with dipalmitoyl phosphatidylcholine (PC16:0/16:0) being the most important molecular species, and about $10 \%$ phosphatidylglycerol (PG). Phospholipid homeostasis may be generally altered in cystic fibrosis since the rate of choline incorporation into PC is increased in isolated blood platelets and fibroblasts from patients with cystic fibrosis. ${ }^{10} \mathrm{It}$ is possible that defective CFTR gene expression may alter surfactant phospholipid homeostasis before colonisation of the lungs with opportunistic bacteria. Since the concentration of surfactant phospholipids and the ratio between individual components, particularly between SP-A and phospholipids, can influence the anti- 
body-independent defence functions of surfactant, ${ }^{11}$ altered phospholipid homeostasis may consequently affect pulmonary integrity. To investigate any such primary alterations in surfactant homoeostasis we analysed the concentration of surfactant phospholipids and SP-A in lungs of $c f t r^{\mathrm{m} 1 \mathrm{HGU} / \mathrm{m} 1 \mathrm{HGU}}$ mice. ${ }^{1213} \mathrm{We}$ further investigated in this mouse model the composition of surfactant phospholipid classes as well as phosphatidylcholine molecular species and, finally, the surface tension function of lung surfactant in comparison with healthy controls. In $c f t r^{\mathrm{m} 1 \mathrm{HGU} / \mathrm{m} 1 \mathrm{HGU}}$ mice a $c f t r$ gene defect was generated by insertional mutagenesis into exon 10 of the $c f t r$ gene $^{12}$ in which aberrant skipping results in the synthesis of 5-10\% wild type transcript and therefore relatively mild symptoms of cftr deficiency. ${ }^{13}$ It was our aim to determine whether there was any primary deviation in pulmonary phospholipids of $c f t r^{\mathrm{m} 1 \mathrm{HGU} / \mathrm{m} 1 \mathrm{HGU}}$ mice in the absence of chronic pulmonary infection. ${ }^{5}$

\section{Methods}

MATERIALS

Specific pathogen-free $c f t r^{\mathrm{m} 1 \mathrm{HGU} / \mathrm{m} 1 \mathrm{HGU}}$ mice supplied from Edinburgh ${ }^{12}$ as well as Ztm:MF1, BALB/cZtm, C57/BL6Ztm, and C3H/HeZtm mice were bred at our local animal house. $c f r^{\mathrm{m} 1 \mathrm{HGU} / \mathrm{m} 1 \mathrm{HGU}}$ mice originated from five different breeding lines. Mice were kept in a flexible film isolator under specified pathogen-free conditions. The hygienic status was tested monthly according to Kunstyr ${ }^{14}$ and the mice were free from murine pathogens. The temperature within the isolator was maintained at $20-24^{\circ} \mathrm{C}$ with $40-50 \%$ relative humidity. Animals were fed an irradiated (5 Mrad) standard diet (Altromin 1314$)$ and autoclaved water $\left(134^{\circ} \mathrm{C}\right.$, 50 minutes) was given ad libitum. Mice subjected to analysis were 5-7 weeks old and the numbers of experiments were not based on any pre-study power calculations. High performance liquid chromatography (HPLC) grade solvents were supplied by Baker (Deventer, Holland). All other solvents and chemicals were of analytical grade and from various commercial sources.

\section{HISTOLOGICAL EXAMINATION}

For histological examination $c f t r^{\mathrm{m} 1 \mathrm{HGU} / \mathrm{m} 1 \mathrm{HGU}}$ mice ( $\mathrm{n}=6,6-10$ weeks old) and MF1 mice $(n=6)$ were sacrificed by cervical dislocation and bled by incision of the abdominal aorta. The thorax was opened and, after perfusing the lung with $1 \mathrm{ml}$ cold phosphate buffered saline via the right ventricle, the trachea was cannulated with a small catheter. The lung was then filled with $1 \mathrm{ml}$ OCT embedding medium (Miles Inc, Elkhart, Indiana, USA) diluted $1: 4$ with $4 \%$ buffered formalin and further immersed in $4 \%$ buffered formalin for fixation. Paraffin-embedded sections $(5 \mu \mathrm{m})$ were prepared and stained with haematoxylin and eosin.
HARVESTING OF BRONCHOALVEOLAR LAVAGE FLUID AND LAVAGED LUNG TISSUE

Animals were anaesthetised with an intraperitoneal injection of $100 \mathrm{mg}$ ketamine hydrochloride (Ketanest, WDT Corporation, Garbsen, Germany) and $4 \mathrm{mg}$ xylocaine hydrochloride (Rompun, Bayer AG, Leverkusen, Germany) per kg body weight prior to sacrifice. This standard procedure was used since it does not cause respiratory depression during anaesthesia. The trachea was cannulated with a small catheter, the abdomen opened, and the animal bled by dissecting the abdominal aorta. The thorax was then opened, the lungs ventilated once with $1 \mathrm{ml}$ of ambient air, and the lung perfused with $154 \mathrm{mM}$ saline at room temperature at a pressure of $15 \mathrm{~cm} \mathrm{H}_{2} \mathrm{O}$ via the right ventricle. The lung was then flushed five times via the tracheal catheter with $1 \mathrm{ml}$ $154 \mathrm{mM}$ saline and the pooled bronchoalveolar lavage (BAL) fluid was centrifuged for $10 \mathrm{~min}-$ utes at $150 \mathrm{~g}$ and $4^{\circ} \mathrm{C}$ to remove cells. The total recovery of BAL fluid was $4.5 \mathrm{ml}$ and did not differ between the experimental groups. BAL fluid and lavaged lungs were frozen at $-80^{\circ} \mathrm{C}$ until further analysis.

PHOSPHOLIPID EXTRACTION

For phospholipid quantitation in cell-free BAL fluid two aliquots of $300 \mu \mathrm{l}$ were placed into phosphate-free glass tubes, the volumes adjusted to $1 \mathrm{ml}$ with $154 \mathrm{mM}$ saline, and this material was extracted with chloroform/methanol according to the method of Bligh and Dyer. ${ }^{15}$ The chloroform extract was dried under a stream of nitrogen and the glass tube directly used for phospholipid quantitation. To quantify phospholipids in subfractions of BAL fluid aliquots of P60000 and S60000 were extracted with chloroform/methanol as outlined above. Lavaged lungs were extracted according to Folch et al, ${ }^{16}$ the extract adjusted to $10 \mathrm{ml}$ with chloroform/methanol 9:1 (v/v) and two aliquots of $100 \mu \mathrm{l}$ used for phospholipid quantitation. Phospholipid phosphorus was determined by the method of Bartlett ${ }^{17}$ after digesting the organic compounds at $190^{\circ} \mathrm{C}$ for 35 minutes in the presence of $500 \mu \mathrm{l} 70 \%$ perchloric acid (w/v) and $200 \mu \mathrm{l} 30 \%$ hydrogen peroxide (w/ v). The amount of phospholipid in total samples was calculated from phospholipid phosphorus in the measured sample aliquots and the original sample volume (BAL fluid, P60000, S60000) or extract volume (total lung extract).

ANALYSIS OF PHOSPHOLIPID CLASSES

The distribution of total phospholipid classes in lipid extracts was determined by normal phase HPLC as described previously. ${ }^{18}$ In brief, aliquots containing 80-100 nmol phospholipid dissolved in chloroform/methanol (1:4 v/v) were resolved isocratically on an aminopropyl silica column (Nucleosil $\mathrm{NH}_{2}, 5 \mathrm{~mm}$, Schambeck, Germany) of $235 \times 4.6 \mathrm{~mm}$ internal diameter. The mobile phase was delivered at a flow rate of $1 \mathrm{ml} / \mathrm{min}$ and comprised acetonitrile/methanol/water/methylphosphonic 
acid (1460:500:30:0.3 v/v/v/v), adjusted to $\mathrm{pH}$ 6.3 by titration with $\mathrm{NH}_{4} \mathrm{OH}(25 \% \mathrm{v} / \mathrm{v}$ in water). Eluted phospholipids were quantitated by fluorescence (excitation wavelength $340 \mathrm{~nm}$, emission wavelength $440 \mathrm{~nm}$ ) after post-column formation of mixed micelles in the presence of 1,6-diphenyl-1,3,5-hexatriene (DPH).

ANALYSIS OF PHOSPHATIDYLCHOLINE

MOLECULAR SPECIES

The composition of individual molecular species of phosphatidylcholine (PC) was determined as previously described by Postle. ${ }^{19}$ A PC fraction was isolated from the total lipid extract on a $100 \mathrm{mg}$ Varian Bondelut $\mathrm{NH}_{2}$ disposable cartridge (Jones Chromatography, Hengoed, Mid Glamorgan, UK). PC molecular species were then resolved on a Spherisorb ODS II column (Schambeck SFD, Bad Honnef, Germany) of internal diameter $250 \times 4.6 \mathrm{~mm}$ at $50^{\circ} \mathrm{C}$ using a mobile phase of methanol/water $(92.5: 7.5 \mathrm{v} / \mathrm{v})$ containing $40 \mathrm{mM}$ choline chloride at a flow rate of $1 \mathrm{ml} /$ min. Eluted PC molecular species were quantified by post-column fluorescence derivative formation as outlined above.

DETERMINATION OF TOTAL PROTEIN AND SP-A Total protein was determined according to the method of Lowry et al. ${ }^{20}$ SP-A was determined by an ELISA technique using polyclonal antihuman SP-A antibodies which cross-reacted with murine SP-A. ${ }^{21}$ Briefly, polyclonal antihuman antibodies were prepared in chickens and New Zealand rabbits by repeated injection of approximately $1 \mathrm{mg}$ purified human SP-A in Freund's complete adjuvant. The chicken and rabbit antisera were then used as the first and second antibodies in a capture ELISA. The microtitre plates (Limbro, ICN Biomedicals Ltd, High Wycombe, Bucks, UK) were coated with chicken anti-human SP-A $\operatorname{IgY}\left(10 \mu \mathrm{g} / \mathrm{ml}\right.$ in $35 \mathrm{mM} \mathrm{Na}_{2} \mathrm{CO}_{3}, \mathrm{pH}$ 9.6) at $4^{\circ} \mathrm{C}$ overnight and the non-specific binding sites were blocked with TBS-NTC $(50 \mathrm{mM}$ Tris, $50 \mathrm{mM} \mathrm{NaCl}, 2 \mathrm{mM} \mathrm{CaCl}, 0.05 \%$ (v/ v) Tween-20, $0.05 \%(\mathrm{w} / \mathrm{v}) \mathrm{NaN}_{3}, \mathrm{pH} 7.4$ ) containing $1 \mathrm{mg} / \mathrm{ml}$ bovine serum albumin for one hour at $37^{\circ} \mathrm{C}$. Purified human SP-A $(10-1000 \mathrm{ng} / \mathrm{ml})$ to be used as standards and BAL fluid samples were duplicated in four serial dilutions in TBS-NTC buffer. The final amounts of SP-A were calculated using these four dilutions. After extensive washes of the wells with TBS-NTC buffer, the samples and standards $(100 \mu \mathrm{l})$ were added to each well and incubated for three hours at $37^{\circ} \mathrm{C}$. After a series of washes with buffer the plates were then incubated with biotinylated rabbit anti-human IgG $(50 \mu \mathrm{g} / \mathrm{ml}, 100 \mu \mathrm{l} /$ well $)$ for two hours at $37^{\circ} \mathrm{C}$. Finally, streptavidin-alkaline phosphatase conjugate (Sigma Chemical Co. Ltd, Poole, Dorset, UK) diluted 1:10000 in TBS-NTC containing $1 \mathrm{mg} / \mathrm{ml}$ BSA was added and allowed to bind for one hour at room temperature. After washing the plates with TBSNTC buffer, $p$-nitrophenyl phosphate (Sigma) was used as a substrate for the phosphatase reaction and incubated for 30 minutes at $37^{\circ} \mathrm{C}$. The reaction was stopped by addition of $1 \mathrm{~N}$ $\mathrm{NaOH}$ and the plate was read at $405 \mathrm{~nm}$. Correlation coefficients of the standard curve were 0.90-0.95. Sample dilutions were adjusted to within the linear range. Total amounts of SP$\mathrm{A}$ in the BAL fluid were calculated from the apparent SP-A concentrations per $\mathrm{ml}$ BAL fluid.

PREPARATION OF SURFACTANT FROM BAL FLUID Surfactant was prepared from cell-free BAL fluid by centrifugation at $60000 \mathrm{~g}$ and $4^{\circ} \mathrm{C}$ for one hour. ${ }^{22}$ The $60000 \mathrm{~g}$ supernatant (S60000) was harvested and frozen at $-80^{\circ} \mathrm{C}$ for further lipid analysis. The $60000 \mathrm{~g}$ pellet (P60000) was resuspended in $60 \mu \mathrm{l} 154 \mathrm{mM}$ saline supplemented with $1.5 \mathrm{mM}$ calcium chloride and the phospholipid concentration determined from an aliquot and then adjusted to the desired concentration for functional analysis (see below).

FUNCTIONAL SURFACTANT ANALYSIS

For functional analysis P60000 was adjusted to $1.33 \mu \mathrm{mol}$ phospholipid/ml with $154 \mathrm{mM}$ saline $/ 1.5 \mathrm{mM}$ calcium chloride. Equilibrium ( $\gamma$ equil) and minimal $(\gamma \mathrm{min})$ surface tensions were then determined using a pulsating bubble surfactometer (Electronetics Co, Amherst, New York, USA). ${ }^{23}$ Briefly, a bubble was created in a surfactant suspension at $37^{\circ} \mathrm{C}$ and requil was determined as surface tension 10 seconds after formation of the bubble. The bubble was then pulsated for five minutes at a frequency of 20 oscillations per min between a minimal bubble radius of $0.4 \mathrm{~mm}$ and a maximal radius of $0.55 \mathrm{~mm}$. The pressure across the bubble was measured by a pressure transducer. $\gamma$ equil and $\gamma$ min were calculated using the LaPlace equation. ${ }^{24}$

\section{DATA ANALYSIS}

Data are expressed as means with $95 \%$ confidence intervals (CI) in parentheses. Statistical analyses were performed by one factor analysis of variance (ANOVA) and the two tailed Student's $t$ test using commercial software (GraphPad InStat Version 1.1, San Diego, USA). Statistical values were corrected for multigroup comparisons using the Bonferroni method and statistical values of regression coefficients were calculated using the same software.

\section{Results}

\section{HISTOLOGICAL EXAMINATION}

The morphology of $c f t r^{\mathrm{m} 1 \mathrm{HGU} / \mathrm{m} 1 \mathrm{HGU}}$ mice showed a regular structure of lung tissue (fig 1). No signs of inflammation as leucocytic infiltration or interstitial oedema were found in any of the animals examined. Comparison of the number and distribution of Clara cells and type II alveolar epithelial cells revealed no detectable differences between MF1 and $c f t r^{\mathrm{m} 1 \mathrm{HGU} / \mathrm{m} 1 \mathrm{HGU}}$ mice. 

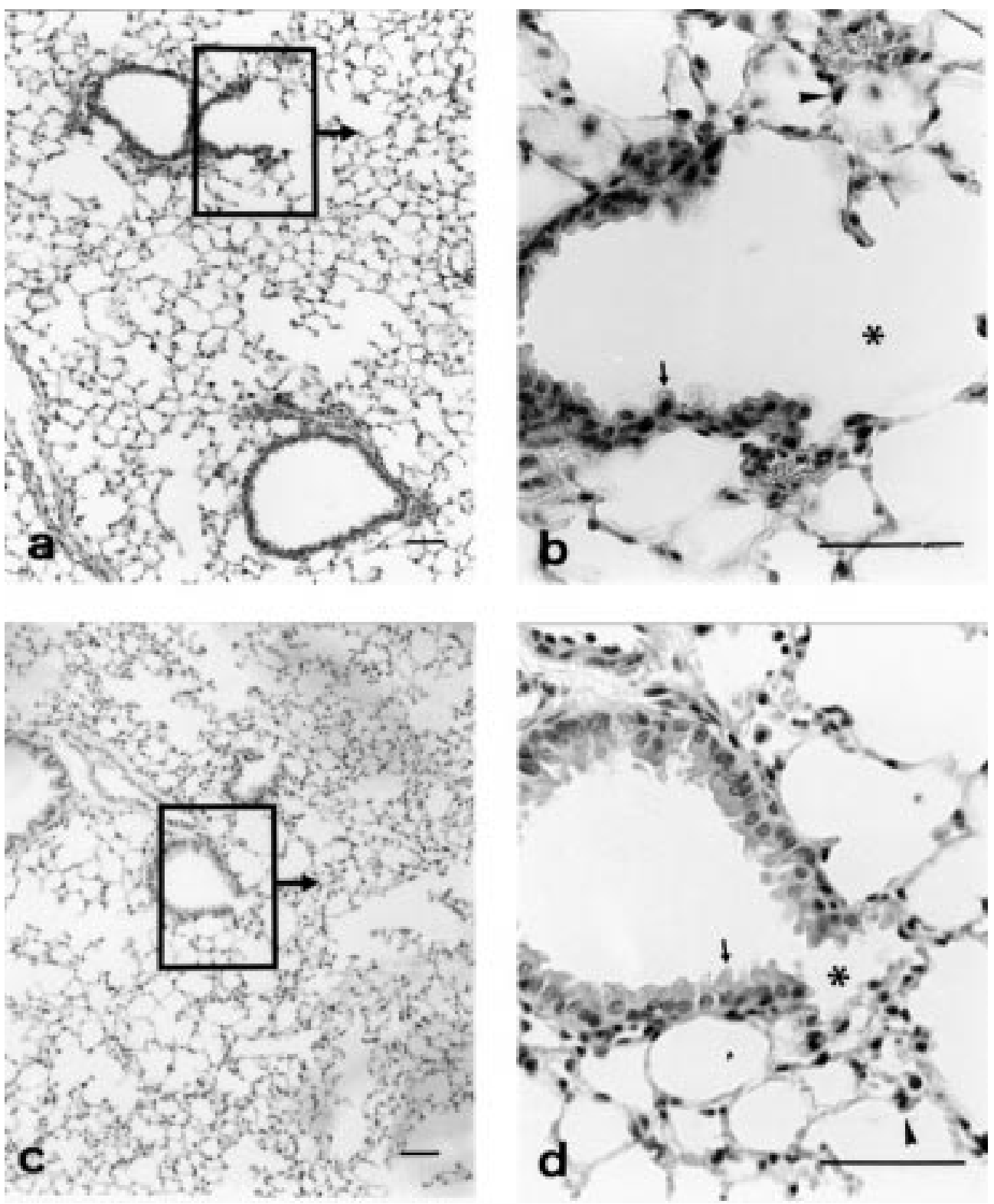

Figure 1 Histological photographs of $\mathrm{cftr}^{\mathrm{m} 1 \mathrm{HGU} / \mathrm{m} 1 \mathrm{HGU}}$ and control mouse lungs. Microphotographs were produced from haematoxylin and eosin stained sections of lung tissue $(5 \mu \mathrm{m})$ from a $\mathrm{cft} \mathrm{r}^{\text {m1HGU/m1HGU }}$ mouse $(a, b)$ and from an MF1 control mouse (c, d). The morphology in both lungs revealed no histopathological findings such as leucocytic infiltration or altered numbers of Clara and type II alveolar epithelial cells. The morphology was similar in all examined animals. $*=$ alveolar duct; $\downarrow=$ Clara cell; $\boldsymbol{\Delta}=$ type II alveolar epithelial cell. Bar represents $50 \mu \mathrm{m}$.

AMOUNT OF PHOSPHOLIPIDS AND SP-A

In BAL fluid from $c f t r^{\mathrm{m} 1 \mathrm{HGU} / \mathrm{m} 1 \mathrm{HGU}}$ mice the amount of phospholipid was 1.02 (95\% CI 0.89 to 1.16$) \mu \mathrm{mol} /$ total BAL fluid but it was significantly lower in controls (table 1 ). In BAL fluid from $\mathrm{BALB} / \mathrm{c}, \mathrm{C} 57 \mathrm{BL} / 6$, and $\mathrm{C} 3 \mathrm{H} / \mathrm{He}$ mice the concentrations of phospholipid were 0.50 (0.42 to 0.57$), 0.52$ (0.40 to 0.64$)$, and 0.45 (0.27 to 0.63$) \mu \mathrm{mol} /$ total BAL fluid, respectively, and in BAL fluid from MF1 mice it was between the values of these controls and $c f t r^{\mathrm{m} 1 \mathrm{HGU} / \mathrm{m} 1 \mathrm{HGU}}$ mice (0.69 (0.63 to 0.75$) \mu \mathrm{mol} /$ total BAL fluid). Assuming that different body weights of the individual mouse strains contributed to the amount of phospholipid in the BAL fluid, we calculated the correlation between body weight and the amount of phospholipid in BAL fluid and lavaged lung tissue.
In both controls and $c f t r^{\mathrm{m} 1 \mathrm{HGU} / \mathrm{m} 1 \mathrm{HGU}}$ mice there were significant positive correlations between the amounts of phospholipid in BAL fluid or lavaged lung tissue and the body weight of the animals (fig 2). We therefore corrected the amount of phospholipid in BAL fluid for the individual body weights of mice. After such correction the amount of phospholipid in total BAL fluid from $c f t r^{\mathrm{m} 1 \mathrm{HGU} / \mathrm{m} 1 \mathrm{HGU}}$ mice was 43.4 (39.0 to 47.9 ) nmol/total BAL fluid/g body weight (table 1), while it was constantly lower in BAL fluid from $\mathrm{MF} 1, \mathrm{BALB} / \mathrm{c}, \mathrm{C} 57 \mathrm{BL} / 6$, and $\mathrm{C} 3 \mathrm{H} / \mathrm{He}$ mice (26.5 (24.7 to 28.5 ), 27.1 (23.0 to 31.2 ), 25.2 (20.4 to 30.0 ), and 22.6 (16.5 to 29.1 ) nmol/total BAL fluid/g body weight, respectively). The relative increase in BAL fluid concentrations of phospholipid in $c f t r^{\mathrm{m} 1 \mathrm{HGU} / \mathrm{m} 1 \mathrm{HGU}}$ mice compared with the in- 
Table 1 Amounts of phospholipid (PL) and apparent surfactant protein A (SP-A) in BAL fluid and of phospholipid in lavaged lung tissue of cftr ${ }^{1 H G U / m 1 H G U}$ mice versus individual healthy control strains

\begin{tabular}{|c|c|c|c|c|c|}
\hline & $\begin{array}{l}c f t r^{m 1 H G U / m 1 H G U} \\
(n=25)\end{array}$ & $\begin{array}{l}M F 1 \\
(n=25)\end{array}$ & $\begin{array}{l}B A L B / c \\
(n=11)\end{array}$ & $\begin{array}{l}C 57 B L / 6 \\
(n=13)\end{array}$ & $\begin{array}{l}\mathrm{C} 3 \mathrm{H} / \mathrm{He} \\
(n=8)\end{array}$ \\
\hline $\mathrm{PL}(\mu \mathrm{mol} / \mathrm{BAL}$ fluid $)$ & $1.02(0.89$ to 1.16$)$ & $0.69(0.63 \text { to } 0.75)^{* * *}$ & $0.50(0.42 \text { to } 0.57)^{* * *}$ & $0.52(0.40 \text { to } 0.64)^{* * *}$ & $0.45(0.27 \text { to } 0.63)^{* * *}$ \\
\hline $\mathrm{PL}(\mu \mathrm{mol} /$ lavaged lung) & 4.04 (3.86 to 4.22$)$ & $4.78(4.54 \text { to } 5.02)^{* * *}$ & $3.32(3.16 \text { to } 3.47)^{* * *}$ & $3.97(3.78$ to 4.16$)$ & 3.63 (3.54 to 3.73$)$ \\
\hline Body weight (g) & $23.3(22.0$ to 24.7$)$ & $26.0(24.8 \text { to } 27.2)^{*}$ & $18.5(17.1 \text { to } 19.8)^{* *}$ & 20.6 (18.3 to 22.9$)$ & $19.9(18.1$ to 21.7$)$ \\
\hline PL (nmol/total BAL fluid/g BW) & $43.4(39.0$ to 47.9$)$ & $26.5(24.7 \text { to } 28.5)^{* * *}$ & 27.1 (23.0 to 31.2$)^{* * *}$ & 25.2 (20.4 to 30.0$)^{* * *}$ & $22.6(16.5 \text { to } 29.1)^{* * *}$ \\
\hline PL (nmol/lavaged lung/g BW) & 175 (166 to 185$)$ & 185 (177 to 193$)$ & 182 (169 to 194$)$ & 197 (185 to 209$)$ & 185 (170 to 200$)$ \\
\hline BAL-PL ( $\%$ of total lung PL) & $19.9(18.0$ to 21.8$)$ & $12.6(11.8 \text { to } 13.4)^{* * *}$ & $13.0(11.2 \text { to } 14.7)^{* * *}$ & $11.3(9.2 \text { to } 13.5)^{* * *}$ & $11.0(7.5 \text { to } 14.5)^{* * *}$ \\
\hline Protein (mg/total BAL fluid) & $0.63(0.52$ to 0.74$)$ & $0.68(0.56$ to 0.80$)$ & $0.67(0.58$ to 0.76$)$ & $0.74(0.67$ to 0.81$)$ & $0.51(0.40$ to 0.61$)$ \\
\hline SP-A (ng/total BAL fluid) & $259(239 \text { to } 279)^{a}$ & $249(222 \text { to } 274)^{\mathrm{b}}$ & 235 (208 to 263 ) & $219(197$ to 241$)$ & $219(159$ to 280$)$ \\
\hline SP-A (ng/nmol PL) & $0.27(0.23 \text { to } 0.31)^{\mathrm{a}}$ & $0.40(0.34 \text { to } 0.46)^{\mathrm{b}}$ & $0.47(0.35 \text { to } 0.58)^{* *}$ & $0.42(0.36$ to 0.53$) *$ & $0.49(0.33 \text { to } 0.63)^{*}$ \\
\hline
\end{tabular}

Data are presented as means and $95 \%$ confidence intervals (in brackets) of the indicated numbers of experiments.

${ }^{\mathrm{a}} \mathrm{n}=14 ;{ }^{b} \mathrm{n}=13$.
${ }^{*} \mathrm{p}<0.05 ; * * \mathrm{p}<0.01, * * * \mathrm{p}<0.001$ versus $c f t r^{\mathrm{m} 1 \mathrm{HGU} / \mathrm{mlHGU}}$.

dividual controls was therefore 64 (52 to 76 ) \%, 60 (39 to 89$) \%, 72$ (45 to 113 )\%, and 92 (49 to 163$) \%$, respectively.

Table 2 Phospholipid composition of bronchoalveolar lavage (BAL) fluid and lung tissue in cftr ${ }^{m 1 H G U / m I H G U}$ mice versus MF1 and other control (BALB/c; C57BL/6; C3H/ He) mice

\begin{tabular}{|c|c|c|c|}
\hline Phospholipid & $\begin{array}{l}c f t r^{m 1 H G U / m 1 H G U} \\
(n=13)\end{array}$ & $\begin{array}{l}M F 1 \\
(n=12)\end{array}$ & $\begin{array}{l}\text { Other controls } \\
(n=21)^{\mathrm{a}}\end{array}$ \\
\hline \multicolumn{4}{|l|}{ BAL fluid } \\
\hline PC & $84.2(81.2$ to 87.1$)$ & 83.3 (81.8 to 84.8$)$ & 85.3 (83.8 to 86.8$)$ \\
\hline PG & 11.1 (9.0 to 13.3$)$ & $12.0(10.6$ to 13.4$)$ & $10.4(7.6$ to 12.0$)$ \\
\hline SPH & $1.1(0.8$ to 1.4$)$ & $0.8(0.4$ to 1.1$)$ & $1.1(0.5$ to 1.5$)$ \\
\hline PE & $2.1(1.2$ to 2.9$)$ & $3.2(2.1$ to 4.5$)$ & $1.1(0.7$ to 1.4$)$ \\
\hline PI & $1.6(1.2$ to 2.0$)$ & $0.7(0.4$ to 1.1$)$ & $2.1(1.2$ to 2.7$)$ \\
\hline \multirow[t]{2}{*}{ PS } & trace & trace & trace \\
\hline & $\begin{array}{l}c f t r^{\mathrm{m} 1 \mathrm{HGU} / \mathrm{m} 1 \mathrm{HGU}} \\
(n=13)\end{array}$ & $\begin{array}{l}M F 1 \\
(n=6)\end{array}$ & $\begin{array}{l}\text { Other controls } \\
(n=25)^{\mathrm{b}}\end{array}$ \\
\hline \multicolumn{4}{|l|}{ Lung tissue } \\
\hline PC & 51.3 (49.8 to 52.9$)$ & 50.0 (48.7 to 51.3$)$ & 49.4 (48.3 to 50.3$)$ \\
\hline PG & $4.2(3.1$ to 5.4$)$ & $4.2(2.5$ to 5.9$)$ & $3.4(2.7$ to 4.1$)$ \\
\hline SPH & $8.2(7.9$ to 8.5$)$ & $8.4(8.0$ to 8.7$)$ & $8.3(8.0$ to 8.6$)$ \\
\hline $\mathrm{PE}$ & 34.1 (31.9 to 36.2$)$ & $36.2(34.1$ to 38.5$)$ & 36.7 ( 35.5 to 37.9$)$ \\
\hline PI & $2.2(1.8$ to 2.6$)$ & $1.2(1.0$ to 1.4$)$ & $2.2(1.8$ to 2.7$)$ \\
\hline PS & trace & trace & trace \\
\hline
\end{tabular}

$\mathrm{Pc}=$ phosphatidylcholine; $\mathrm{PG}=$ phosphatidylglycerol; $\mathrm{SPH}=$ sphingomyelin; $\mathrm{PE}=$ phosphatidylethanolamine; PI = phosphatidylinositol; PS = phosphatidylserine.

${ }^{a} \mathrm{BALB} / \mathrm{c}(\mathrm{n}=7), \mathrm{C} 57 \mathrm{BL} / 6(\mathrm{n}=8)$ and C3H/HE $(\mathrm{n}=6) .{ }^{\mathrm{b}} \mathrm{BALB} / \mathrm{c}(\mathrm{n}=11), \mathrm{C} 57 \mathrm{BL} / 6(\mathrm{n}=8)$ and $\mathrm{C} 3 \mathrm{H} / \mathrm{He}(\mathrm{n}=6)$.

Table 3 Molecular species of phosphatidylcholine (PC) in bronchoalveolar lavage (BAL) fluid and lung tissue in cftr ${ }^{\text {mHGUm1HGU }}$ versus $M F 1$ and other control (BALB/c; $\mathrm{C} 57 \mathrm{BL} / 6 ; \mathrm{C} 3 \mathrm{H} / \mathrm{He}$ ) mice

\begin{tabular}{|c|c|c|c|}
\hline PC species & $\begin{array}{l}c f t r^{m 1 H G U / m 1 H G U} \\
(n=9)\end{array}$ & $\begin{array}{l}M F 1 \\
(n=14)\end{array}$ & $\begin{array}{l}\text { Other controls } \\
(n=17)^{\mathrm{a}}\end{array}$ \\
\hline \multicolumn{4}{|l|}{ BAL fluid } \\
\hline PC16:0/14:0 & $5.3(4.9$ to 5.8$)$ & $5.7(5.3$ to 6.1$)$ & 4.7 (3.9 to 5.4$)$ \\
\hline PC16:0/16:0 & $57.9(56.4$ to 59.4$)$ & $58.3(57.3$ to 59.3$)$ & 58.3 (56.0 to 60.7$)$ \\
\hline PC16:0/16:1 & $19.8(18.8$ to 20.9$)$ & $17.9(16.9$ to 18.9$)$ & $13.5(10.3 \text { to } 16.8)^{*}$ \\
\hline PC16:0/18:1 & $4.5(4.1$ to 5.0$)$ & $5.2(5.0$ to 5.4$)$ & $7.2(6.4 \text { to } 8.0)^{* * * *}$ \\
\hline PC16:0/18:2 & 6.3 (5.6 to 6.9$)$ & $6.9(6.5$ to 7.2$)$ & $9.0(8.0 \text { to } 9.9)^{* *}$ \\
\hline PC18:0/18:2 & $0.4(0.2$ to 0.6$)$ & $0.2(0.1$ to 0.3$)$ & $1.2(0.4$ to 2.0$)$ \\
\hline PC16:0/20:4 & $1.1(0.9$ to 1.2$)$ & $1.2(0.6$ to 2.6$)$ & $1.4(1.1$ to 1.7$)$ \\
\hline PC18:0/20:4 & $0.4(0.2$ to 0.6$)$ & $0.2(0.1$ to 0.3$)$ & $0.8(0.5$ to 1.2$)$ \\
\hline PC18:1/18:2 & $0.4(0.2$ to 0.5$)$ & $0.5(0.1$ to 0.9$)$ & $0.5(0.3$ to 0.7$)$ \\
\hline \multirow[t]{2}{*}{ Others } & $3.9(2.9$ to 4.9$)$ & 3.7 (3.3 to 4.1$)$ & $3.4(2.7$ to 4.3$)$ \\
\hline & $\begin{array}{l}c f t r^{\mathrm{m} 1 \mathrm{HGU} / \mathrm{m} 1 \mathrm{HGU}} \\
(n=16)\end{array}$ & $\begin{array}{l}M F 1 \\
(n=23)\end{array}$ & $\begin{array}{l}\text { Other controls } \\
(n=17)\end{array}$ \\
\hline \multicolumn{4}{|l|}{ Lung tissue } \\
\hline PC16:0/14:0 & $3.6(3.0$ to 4.1$)$ & $4.0(3.5$ to 4.5$)$ & 2.9 (2.6 to 3.1$)$ \\
\hline PC16:0/16:0 & $34.8(33.2$ to 36.3$)$ & $35.6(34.8$ to 36.3$)$ & $33.2(32.1$ to 34.3$)$ \\
\hline PC16:0/16:1 & $10.8(9.9$ to 11.8$)$ & $8.4(7.8 \text { to } 9.1)^{* *}$ & $7.8(6.5 \text { to } 9.0)^{* * * *}$ \\
\hline PC16:0/18:1 & $11.1(10.2$ to 12.0$)$ & $14.2(13.5 \text { to } 15.0)^{* * *}$ & 12.9 (12.6 to 13.3$)^{*}$ \\
\hline PC16:0/18:2 & $10.8(10.1$ to 11.4$)$ & $10.2(9.3$ to 11.2$)$ & $11.6(11.1$ to 12.2$)$ \\
\hline PC18:0/18:2 & $3.6(3.5$ to 3.8$)$ & $3.3(2.9$ to 3.6$)$ & $4.0(3.7$ to 4.3$)$ \\
\hline PC16:0/20:4 & $4.3(4.0$ to 4.6$)$ & $4.0(3.6$ to 4.4$)$ & $4.9(4.6$ to 5.2$)$ \\
\hline PC18:0/20:4 & $4.0(3.7$ to 4.4$)$ & 3.8 (3.3 to 4.2$)$ & $4.8(4.5$ to 5.2$)$ \\
\hline PC16:0/22:6 & $3.4(3.1$ to 3.7$)$ & $4.9(4.4$ to 5.4$)$ & $3.2(3.0$ to 3.5$)$ \\
\hline PC18:1/18:2 & $1.4(1.2$ to 1.6$)$ & $2.7(1.4$ to 3.9$)$ & $1.6(1.4$ to 1.7$)$ \\
\hline Others & $12.2(11.5$ to 12.9$)$ & $8.9(8.1$ to 9.7$)$ & $13.2(12.5$ to 13.9$)$ \\
\hline
\end{tabular}

PC16:0/14:0= palmitoylmyristoyl-PC; PC16:0/16:0= dipalmitoyl-PC; PC16:0/16:1 = palmitoylpalmitoleoyl-PC; PC16:0/18:1 = palmitoyloleoyl-PC; PC16:0/18.2=palmitoyllinoleoyl-PC; PC18:0/18:2=stearoyllinoleoyl-PC; PC16:0/20:4=palmitoylarachidonoyl-PC; PC18:1/18:2= oleoyllinoleoyl-PC; others $=$ minor identified (dioleoyl-PC, stearoyloleoyl-PC) or not identified PC species.

Data are means and $95 \%$ confidence intervals (in brackets) of the indicated numbers (n) of experiments. ${ }^{\mathrm{a}} \mathrm{BALB} / \mathrm{c}(\mathrm{n}=10), \mathrm{C} 57 \mathrm{BL} / 6(\mathrm{n}=4)$ and $\mathrm{C} 3 \mathrm{H} / \mathrm{He}(\mathrm{n}=3)$.
In lavaged lung tissues from $c f t r^{\mathrm{m} 1 \mathrm{HGU} / \mathrm{m} 1 \mathrm{HGU}}$ mice the amount of phospholipid was 4.04 (3.86 to 4.22$) \mu \mathrm{mol} /$ whole lung and 175 (166 to 185) $\mathrm{nmol} /$ whole lavaged lung/g body weight. While the absolute values per lavaged lung displayed some significant differences between $c f t r^{\mathrm{m} 1 \mathrm{HGU} / \mathrm{m} 1 \mathrm{HGU}}$ mice and two of the control strains - namely, MF1 and BALB/c - there were no significant differences after correcting these values for body weight (table 1). Consequently, BAL fluid from $c f t r^{\mathrm{m} 1 \mathrm{HGU} / \mathrm{m} 1 \mathrm{HGU}}$ mice contained 19.9 (18.0 to 21.8 ) $\mathrm{mol} \%$ of total lung phospholipid (BAL fluid + lavaged lung), while in $\mathrm{MF} 1, \mathrm{BALB} / \mathrm{c}, \mathrm{C} 57 \mathrm{BL} / 6$, and $\mathrm{C} 3 \mathrm{H} /$ $\mathrm{He}$ mice the BAL fluid contained only 12.6 (11.8 to 13.4 ) $\mathrm{mol} \%, 13.0$ (11.2 to 14.7 ) $\mathrm{mol} \%$, 11.3 (9.2 to 13.5$) \mathrm{mol} \%$, and 11.0 (7.5 to 14.5 ) mol\%, respectively (table 1 ). The apparent concentration of SP-A, a major component of
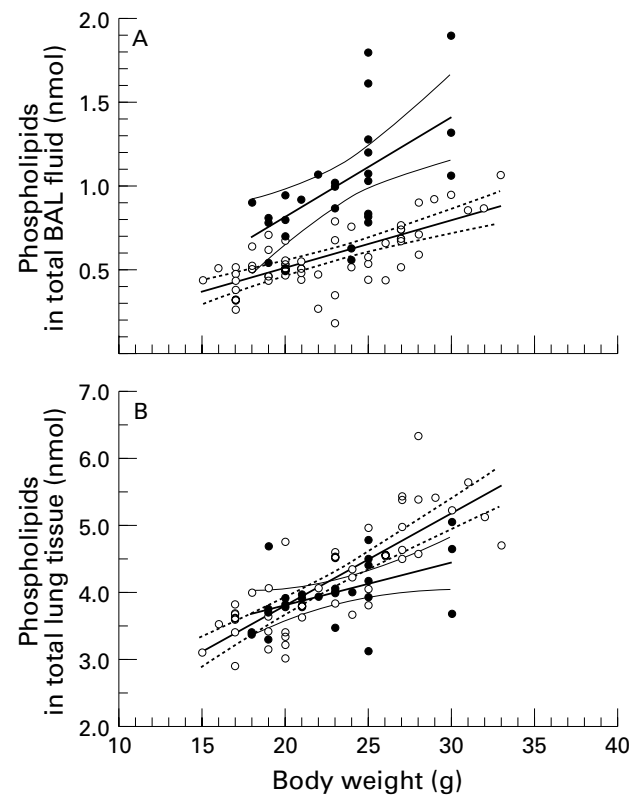

Figure 2 Correlation between the amounts of lung phospholipid and body weight. Linear regression curves were calculated between the total amount of phospholipids in (A) BAL fluid or (B) lavaged lung tissue from

cftr $^{m 1 H G U / m 1 H G U}(\mathbf{O} ; n=25)$ and control mice $(\bigcirc ; n=57)$ and the individual body weights of the mice. Thick bars represent regression curves while thin (cftrm ${ }^{m H G U}$ imIHGU mice) or dotted (control) lines represent $95 \%$ confidence intervals. In BAL fluid of cftrm ${ }^{m 1 H G U / m 1 H G U}$ mice $r=0.591$, $p<0.01$; controls $r=0.671, p<0.00001$. In lung tissue of cftr ${ }^{m 1 H G U / m 1 H G U}$ mice $r=0.458, p<0.05$; controls $r=0.826, p<0.00001$. 


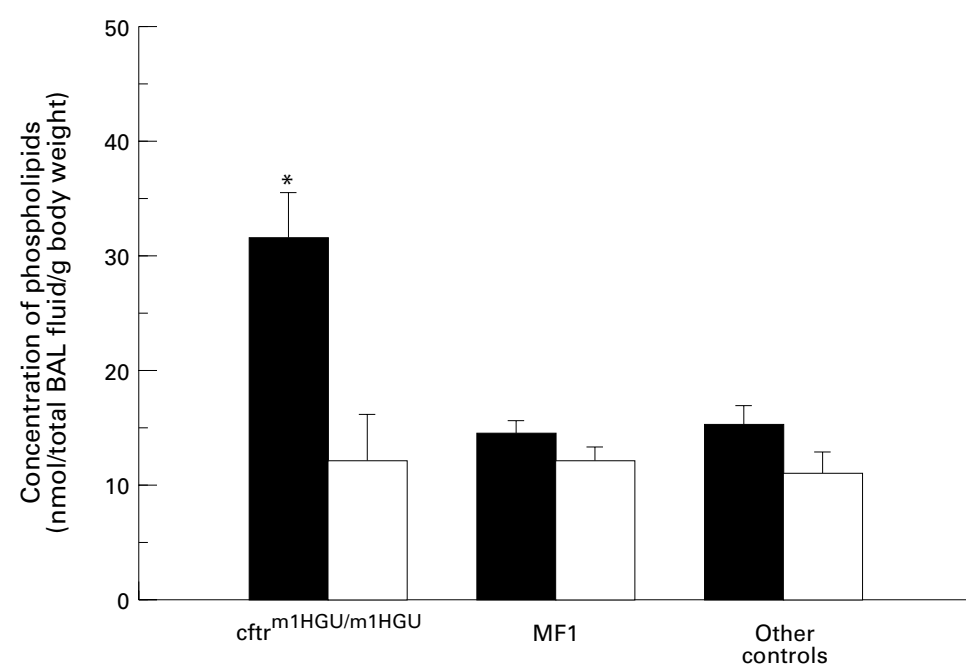

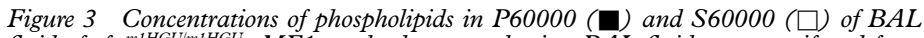
fluid of cftr ${ }^{m 1 H G U / m 1 H G U}, M F 1$, and other control mice. BAL fluid was centrifuged for one hour at $60000 \mathrm{~g}$ and at $4^{\circ} \mathrm{C}$. Phospholipid concentrations were determined in the pellet (P60000) and supernatant (S60000) as described in the Methods section. cftr ${ }^{\text {m1HGUlm1HGU }}$ $(n=6) ; M F 1(n=3)$; other control mice: $B A L B / c(n=4) ; C 57 B L / 6(n=3) ; C 3 H / H e$ $(n=5)$. Bar height represents 95 confidence interval. ${ }^{*} p<0.05$ versus $M F 1$ and other controls.

Table 4 Surface tension function (in $\mathrm{mN} / \mathrm{m}$ ) of $60000 \mathrm{~g}$ pellet (P60000) from

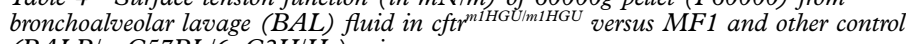
$(B A L B / c ; C 57 B L / 6 ; C 3 H / H e)$ mice

\begin{tabular}{|c|c|c|c|}
\hline PC species & $\begin{array}{l}c f t r^{m 1 H G U / m 1 H G U} \\
(n=7)\end{array}$ & $\begin{array}{l}M F 1 \\
(n=7)\end{array}$ & $\begin{array}{l}\text { Other controls } \\
(n=13)^{\mathrm{a}}\end{array}$ \\
\hline 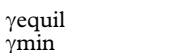 & 24.7 (19.1 to 30.3$)$ & $25.0(24.2$ to 25.9$)$ & 28.6 (25.5 to 31.6$)$ \\
\hline Pulsation 1 & $17.4(14.4$ to 20.5$)$ & $21.6(20.0$ to 23.1$)$ & $18.2(13.4$ to 22.9$)$ \\
\hline Pulsation 3 & $15.6(11.3$ to 19.8$)$ & $18.0(13.1$ to 22.9$)$ & 16.6 (10.8 to 22.4$)$ \\
\hline Pulsation 9 & $11.1(5.3$ to 16.8$)$ & $13.6(7.0$ to 20.2$)$ & 15.5 (10.1 to 20.9$)$ \\
\hline Pulsation 100 & $2.8(0.1$ to 5.5$)$ & $3.2(0.1$ to 6.7$)$ & $2.6(1.7$ to 3.5$)$ \\
\hline
\end{tabular}

yequil $=$ equilibrium surface tension; $\gamma \min =$ minimal surface tension.

Data are means and $95 \%$ confidence intervals (in brackets) of the indicated numbers ( $\mathrm{n}$ ) of experiments.

${ }^{\mathrm{a}} 13$ experiments from $\mathrm{BALB} / \mathrm{c}(\mathrm{n}=4), \mathrm{C} 57 \mathrm{BL} / 6(\mathrm{n}=5)$, and $\mathrm{C} 3 \mathrm{H} / \mathrm{He}(\mathrm{n}=4)$ mice.

surfactant and important for its interactions with type II alveolar cells, phospholipids, bacteria and alveolar macrophages, was 259 (239 to 279) $\mathrm{ng} /$ total BAL fluid of $c f t r^{\mathrm{m} 1 \mathrm{HGU} / \mathrm{m} 1 \mathrm{HGU}}$ mice which was identical to the concentrations in BAL fluid of control mice (table 1). Due to the increase in the concentration of phospholipids in the BAL fluid, the ratio of SP-A to phospholipid was decreased by $33-45 \%$ from 0.40 (0.34 to 0.46$), 0.47$ (0.35 to 0.58$), 0.42$ (0.36 to 0.53 ), and 0.49 (0.33 to 0.63$)$, respectively, in the individual control strains to 0.27 (0.23 to 0.31 ) in $c f r^{\mathrm{m} 1 \mathrm{HGU} / \mathrm{m} 1 \mathrm{HGU}}$ mice (table 1$)$.

COMPOSITION OF PHOSPHOLIPID CLASSES AND PHOSPHATIDYLCHOLINE (PC) MOLECULAR SPECIES

Investigation of phospholipid compositional changes in BAL fluid and lung tissue of $c f t r^{\mathrm{m} 1 \mathrm{HGU} / \mathrm{m} 1 \mathrm{HGU}}$ mice was in the first instance addressed by HPLC analysis of phospholipid classes. As shown in table 2 there were no differences in the relative composition of phospholipid classes in BAL fluid and lung tissue of $c f t r^{\mathrm{m} 1 \mathrm{HGU} / \mathrm{m} 1 \mathrm{HGU}}$ and control mice. Importantly, the contributions of PC and phosphatidylglycerol (PG) were not decreased, nor were those of sphingomyelin (SPH) or phosphatidylethanolamine (PE) increased in either BAL fluid or lung tissue of $c f t r^{\mathrm{m} 1 \mathrm{HGU} / \mathrm{m} 1 \mathrm{HGU}}$ mice. Because there were no differences in the phospholipid compositions of $\mathrm{BALB} / \mathrm{c}, \mathrm{C} 57 \mathrm{BL} / 6$ and $\mathrm{C} 3 \mathrm{H} / \mathrm{He}$ mice, these data were combined and are shown as "other controls". Since the key molecule of surface tension function of lung surfactant is PC16:0/16:0, and since alterations in the concentrations of individual molecular species of PC are a more sensitive indicator of pulmonary surfactant alterations than the determination of PC fatty acids by gas chromatography, ${ }^{19}$ we subsequently investigated these PC molecular species in both BAL fluid and lavaged lung tissue. The BAL fluid and lavaged lung tissue of $c f t r^{\mathrm{m} 1 \mathrm{HGU} / \mathrm{m} 1 \mathrm{HGU}}$ mice predominantly contained PC16:0/16:0 (table 3), comprising 57.9 (56.4 to 59.4 ) $\mathrm{mol} \%$ and 34.8 (33.2 to 36.3 ) $\mathrm{mol} \%$ of total PC, respectively. These values were identical to those from control mice. Other typical components of surfactant - for example, palmitoylmyristoyl-PC (PC16:0/14:0) and palmitoylpalmitoleoyl-PC (PC16:0/16:1) - were also without major changes in $c f t r^{\mathrm{mlHGU} / \mathrm{m} 1 \mathrm{HGU}}$ mice compared with controls. The highly unsaturated PC species palmitoylarachidonoylPC (PC16:0/20:4), stearoylarachidonoylPC (PC18:0/20:4), and palmitoyldocosahexaenoyl-PC (PC16:0/22:6) were not detected in significant amounts in BAL fluid but made up $12-14 \%$ in lung tissue. Again, there were no major differences between $c f t r^{\mathrm{m} 1 \mathrm{HGU} / \mathrm{m} 1 \mathrm{HGU}}$ and control mice.

SURFACE TENSION FUNCTION OF SURFACTANT IN BAL FLUID

The relative concentration of active surfactant isolated by differential ultracentrifugation at $60000 \mathrm{~g}$ (P60000) compared with the phospholipids in the supernatant (S60000) of the BAL fluid is shown in fig 3. In BAL fluid from $c f t r^{\mathrm{m} 1 \mathrm{HGU} / \mathrm{m} 1 \mathrm{HGU}}$ mice the amount of phospholipid in P60000 was significantly higher than in controls. To evaluate whether the surface tension function of the P60000 was different from that of controls we measured the surface tension function of this material. Equilibrium surface tension ( $\gamma$ equil) after 10 seconds of static adsorption of P60000 from $c f t r^{\mathrm{m} 1 \mathrm{HGU} / \mathrm{m} 1 \mathrm{HGU}}, \mathrm{MF} 1$, and other control mice was 24.7 (19.1 to 30.3$) \mathrm{mN} / \mathrm{m}, 25.0$ (24.2 to 25.9) $\mathrm{mN} / \mathrm{m}$, and $28.6(25.5$ to 31.6$) \mathrm{mN} / \mathrm{m}$, respectively (table 4$)$. Dynamic measurement of minimal surface tension $(\gamma \mathrm{min})$ showed that P60000 from $c f t r^{\mathrm{m} 1 \mathrm{HGU} / \mathrm{m} 1 \mathrm{HGU}}$ mice reached values below $5 \mathrm{mN} / \mathrm{m}$ as quickly as surfactant from the control mice (table 4).

\section{Discussion}

Cystic fibrosis is an inherited disease with a defect in the CFTR gene resulting in the expression of a defective cAMP-dependent chloride channel. ${ }^{12}$ Previous reports of impairment to the biophysical properties of airway secretions, as well as lipid extracts of such secretions in patients with cystic fibrosis as- 
sociated with an altered phospholipid composition, have been attributed to the associated chronic inflammatory processes. ${ }^{1-5}$ The possibility of a primary defect in surfactant processing in cystic fibrosis has not previously been considered. ${ }^{1225}$ However, recent RNA in situ hybridisation studies have demonstrated that the CFTR gene is expressed in the lung periphery in type II alveolar epithelial cells which produce both surfactant proteins and phospholipids. ${ }^{67}$ Moreover, an increased phospholipid turnover was described in isolated human fibroblasts and blood platelets from patients with cystic fibrosis. ${ }^{10}$ Hence, lung surfactant metabolism could be affected by the basic defect of cystic fibrosis prior to and independent from the chronic inflammatory processes in the lungs. ${ }^{1225}$ To address this issue we employed the $c f t r^{\mathrm{m} 1 \mathrm{HGU} / \mathrm{m} 1 \mathrm{HGU}}$ mouse $^{12}$ as an animal model to study aspects of lung surfactant metabolism in cystic fibrosis prior to chronic pulmonary infection. The $c f t r^{\mathrm{m} 1 \mathrm{HGU} / \mathrm{m} 1 \mathrm{HGU}}$ mouse is a useful model for human cystic fibrosis because, unlike the absolute "null" mutant mouse, this model shows normal growth rate and good long term survival. This is due to the "leaky" nature of the mutation which results in $5-10 \%$ residual wild type after expression. The $c f t r^{\mathrm{m} 1 \mathrm{HGU} / \mathrm{m} 1 \mathrm{HGU}}$ mouse is thus analogous to patients with cystic fibrosis carrying CFTR mutations which retain partial CFTR function.

Our data show, for the first time, that BAL fluid concentrations of surfactant phospholipid as an index for the intra-alveolar surfactant pool are primarily increased by about $60 \%$ in a CFTR-deficient organism compared with all other tested control strains, whereas the amount of phospholipid in lung tissue is not altered. While we could not demonstrate biochemical alterations of alveolar phospholipid material, the quantitative changes in alveolar surfactant phospholipids were due to an increase in material which could be pelleted by ultracentrifugation at $60000 \mathrm{~g}$ (P60000) as previously described in the mouse by other investigators. ${ }^{22}$ In that study it was demonstrated that the P60000 consisted of large surfactant aggregates, while so-called small surfactant aggregates remained in the $60000 \mathrm{~g}$ supernatant (S60000). Moreover, it was demonstrated that P60000 consisted of surface active material while $S 60000$ contained only inactive material. Our functional data are consistent with these observations since P60000 present in BAL fluid from both $c f t r^{m 1 \mathrm{HGU} / \mathrm{m} 1 \mathrm{HGU}}$ and control mice was highly surface active. It was suggested that, during the dynamic processing of surfactant from its secretion to its re-uptake into type II pneumocytes, P60000 represents freshly secreted surface active material while S60000 represents inactivated "older" surfactant which shows poor surface tension function. ${ }^{22} 26$ It is therefore reasonable to attribute the increased alveolar surfactant pool size in $c f t r^{\mathrm{m} 1 \mathrm{HGU} / \mathrm{m} 1 \mathrm{HGU}}$ mice to an increase in newly secreted active surfactant ("large aggregates") rather than an accumulation of inactivated older surfactant ("small aggregates") ${ }^{22}$ in the alveolar space. ${ }^{27}$
Several mechanisms could lead to an accumulation of surfactant phospholipid in the alveolar space. Decreased clearance of surfactant along the conductive airways due to the impaired bronchopulmonary clearance in CFTR deficiency is unlikely to play a major role since this is typically a minor route for surfactant clearance. ${ }^{27}$ Recent findings in isolated cells from patients with cystic fibrosis, however, support the concept that a primary alteration of phospholipid metabolism ${ }^{10}$ may contribute to this increased surfactant phospholipid pool in the alveolus. In isolated fibroblasts and platelets from patients with cystic fibrosis phospholipid synthesis was increased, but such cells do not secrete major amounts of phospholipid. However, despite the tempting explanations outlined above, other explanations for an increase in surfactant phospholipids in the alveolar space should be mentioned. The $c f t r$ gene transcript regulates the cAMP-dependent $\mathrm{Cl}^{-}$current and thereby the transport of other ions and of water through cells. ${ }^{2}$ Cftr expression in type II alveolar epithelial cells ${ }^{67}$ could indirectly alter the homeostasis of the watery alveolar hypophase and of cAMP, thereby influencing surfactant phospholipid homeostasis.

The alterations in $c f t r^{\mathrm{m} 1 \mathrm{HGU} / \mathrm{m} 1 \mathrm{HGU}}$ mice described in this study are different from those previously described in chronically infected airways of human subjects. While in studies on airway secretions from patients with cystic fibrosis alterations in phospholipid classes, fatty acid composition of phospholipids, and biophysical properties (adsorption velocity) were described, ${ }^{25}$ we did not detect such changes in BAL fluid from $c f t r^{\mathrm{m} 1 \mathrm{HGU} / \mathrm{m} 1 \mathrm{HGU}}$ mice without infection. Similarly, no impairment of surface tension function of the surfactant isolated from the BAL fluid of $c f t r^{\mathrm{m} 1 \mathrm{HGU} / \mathrm{m} 1 \mathrm{HGU}}$ mice was detected. We therefore conclude that such alterations are due to chronic inflammation and leucocyte infiltration of cystic fibrosis lungs, secondary to colonisation with opportunistic bacteria. Our data support the concept that any alteration in the phospholipid composition is due to chronic infection and inflammation rather than an effect of CFTR mutations.

While phospholipids were increased in the BAL fluid, the amount of SP-A remained unchanged. This unexpected finding is in agreement with a recent study by Doyle et al who showed that phospholipid and SP-A secretion into the alveolus are independently regulated. ${ }^{26}$ While the mechanisms of such changes in $c f t r^{\mathrm{m} 1 \mathrm{HGU} / \mathrm{m} 1 \mathrm{HGU}}$ mice are still uncertain and await further investigation, the potential consequences for pulmonary defence of an increased amount of phospholipid and a decreased ratio of SP-A to phospholipid are more obvious. Surfactant contributes to pulmonary integrity as a first line of defence. ${ }^{11}$ Phospholipid inhibits the activity of SP-A to opsonise bacteria and depresses the respiratory burst of alveolar macrophages upon challenge. ${ }^{1128}$ Increased phospholipid concentrations together with a decreased SP-A to phospholipid ratio in $c f t r^{\mathrm{m} 1 \mathrm{HGU} / \mathrm{m} 1 \mathrm{HGU}}$ mice, and possibly in patients with cystic fibrosis, may 
impair the resistance of the lungs against bacteria. ${ }^{28}$ Since human SP-A was used as a standard in the immunoassay, the values obtained for the mouse SP-A are not absolute and are only for use for the comparison of SP-A levels within the different strains of mice examined in this study. Nevertheless, our results are consistent with recent findings on BAL fluid from patients with cystic fibrosis which showed an increased concentration of PC, while the ratio between SP-A and phospholipid was even more decreased in the BAL fluid of patients with cystic fibrosis than in that of $\mathrm{cftr}^{\mathrm{m} 1 \mathrm{HGU} / \mathrm{m} 1 \mathrm{HGU}}$ mice. ${ }^{29}$ However, while the data from human BAL fluid originate from lungs that already show symptoms of chronic impairment and, possibly, proteolytic degradation of SP-A due to inflammation, the $c f t^{\mathrm{m} 1 \mathrm{HGU} / \mathrm{m} 1 \mathrm{HGU}}$ mice used in this study were kept under specific pathogenfree conditions. Histological examination of lungs confirmed the absence of leucocytic infiltrations or other visible alteration of lung structure and cellular distribution, and the absence of increases in membrane phospholipids such as PE or SPH in BAL fluid from cftr ${ }^{\mathrm{m} 1 \mathrm{HGU} / \mathrm{m} 1 \mathrm{HGU}}$ mice provides further evidence of minimal damage to their lungs. It is therefore possible that the greater decrease in the SP-A to phospholipid ratio in BAL fluid from patients with cystic fibrosis ${ }^{29}$ compared with $c f t r^{\mathrm{m} 1 \mathrm{HGU} / \mathrm{m} 1 \mathrm{HGU}}$ mice may in part be due to secondary degradation of SP-A caused by chronic inflammation of the lung.

We conclude that, in $c f t r^{\mathrm{m} 1 \mathrm{HGU} / \mathrm{m} 1 \mathrm{HGU}}$ mice without chronic inflammatory lung disease, the composition of phospholipid classes and phosphatidylcholine molecular species, the concentration of SP-A, and the surface tension function of surfactant are all unchanged compared with control mice. However, the total amount of phospholipid and the ratio of phospholipid to SP-A was increased in the BAL fluid, possibly as a result of altered surfactant phospholipid metabolism.

The authors acknowledge the expert advice of Professor K B M Reid (Oxford University, Oxford, UK) and A D Postle (Southampton University, Southampton, UK) and the excellent technical assistance of Mrs Ch Acevedo and Mrs K Westermann. This work was supported by the Deutsche Forschungsgemeinschaft (Ha 1959/1-2; 2-1) and the Medical Research Council.

1 Boat T, Welsh MJ, Beaudet A. Cystic fibrosis. In: Scriver C, Beaudet A, Sly W, Valle D, eds. The metabolic basis of inherited disease. 6th ed, New York: McGraw-Hill, 1989: 2649-80.

2 Marino CR, Gorelick FS. Scientific advances in cystic fibrosis. Gastroenterology 1992;103:681-93.

3 Chase KV, Leathy DS, Martin R, Carubelli R, Flux M, Sachdev GP. Respiratory mucous secretions in patients Sachdev GP. Respiratory mucous secretions in patients
with cystic fibrosis: relationship between levels of highly with cystic fibrosis: relationship between levels of highly Chim Acta 1983;132:143-55.

4 Puchelle E, Jacquot J, Beck G, Zahm JM, Galabert C. Rheological properties of airway secretions in cystic fib- rosis: relationship between the degree of infection and severity of the disease. Eur F Clin Invest 1985;15:389-94. 5 Galabert C, Jacquot J, Zahm JM, Puchelle E. Relationship between the lipid content and the rheological properties of airway secretions in cystic fibrosis. Clin Chim Acta 1987; 164:139-49.

6 McCray PB, Wohlford-Lenane CL, Snyder JM. Localization of cystic fibrosis transmembrane conductance regulator mRNA in human fetal lung tissue by in situ hybridization. f Clin Invest 1992;90:619-25.

7 Engelhardt JF, Zepeda M, Cohn JA, Yankaskas JR, Wilson JM. Expression of the cystic fibrosis gene in adult human lung. F Clin Invest 1993;93:737-49.

8 Sugahara K, Iyama K, Sano K, Morioka T. Differential expressions of surfactant protein SP-A, SP-B and SP$\mathrm{D}$ mRNA in rats with streptozotocin-induced diabetes $\mathrm{D}$ mRNA in rats with streptozotocin-induced diabetes Mol Biol 1994;11:397-404

9 Crouch E, Parghi D, Kuan S-F, Persson A. Surfactant protein D: subcellular localization in nonciliated bronchiolar epithelial cells. Am f Physiol 1992;263 (Lung Cell Mol Physiol 7):L60-6.

10 Ulane MM, Butler DeB, Peri A, Miele L, Ulane RE Hubbard VS. Cystic fibrosis and phosphatidylcholine biosynthesis. Clin Chim Acta 1994;230:109-16.

11 Van Golde LMG. Potential role of surfactant proteins A and $\mathrm{D}$ in innate lung defense against pathogens. Bio Neonate 1995; 67(Suppl 1):2-17.

12 Dorin JR, Dickinson P, Alton EWFW, Smith SN, Geddes $\mathrm{DM}$, Stevenson BJ, et al. Cystic fibrosis in the mouse by targeted insertional mutagenesis. Nature 1992;359:211-5.

13 Dorin JR, Stevenson BJ, Fleming S, Alton EWFE, Dickinson $\mathrm{P}$, Porteous DJ. Long term survival of the exon 10 insertional cystic fibrosis mutant mice is a consequence sertional cystic fibrosis mutant mice is a consequence Mammalian Genome 1994;5:465-72.

14 Kunstyr I, ed. Diagnostic microbiology for laboratory animals. GV-SOLAS, Vol. 11, 1st ed. Stuttgart/Jena/New York: G Fischer, 1992 .

15 Bligh EG, Dyer WJ. A rapid method of total lipid extraction and purification. Can ₹ Biochem Physiol 1959;37:911-7.

16 Folch J, Lees M, Stanley GHS. A simple method for the isolation and purification of total lipids from animal tissues. F Biol Chem 1957;226:497-509.

17 Bartlett GR. Phosphorus assay in column chromatography. f Biol Chem 1959;234:466-8.

18 Bernhard W, Linck M, Creutzburg H, Postle AD, Arning A, Martin-Carrera I, et al. High-performance liquid chromatographic analysis of phospholipids from differen sources with combined fluorescence and ultraviolet detection. Anal Biochem 1994;220:172-80.

19 Postle AD. Method for the sensitive analysis of individual molecular species of phosphatidylcholine by high-performance liquid chromatography using post colum fluorescence detection. F Chromatogr 1987; 419:24151.

20 Lowry OH, Rosebrough NJ, Farr AL, Randall AL. Protein measurement with the folin phenol reagent. $7 \mathrm{Biol}$ Chem 1951;193:265-75.

21 Wang J-Y, Yeh T-F, Lin Y-C, Miyamura K, Holmskov U, Reid KBM. Measurement of pulmonary status and surfactant protein levels during dexamethasone treatment of neonatal respiratory distress syndrome. Thorax 1996; 51:907-13.

22 Oulton M, MacDonald J, Janigan DT, Faulkner GT. Mouse alveolar surfactant: characterization of subtypes prepare by differential centrifugation. Lipids 1993;28:715-20.

23 Enhorning G. Pulsating bubble technique for evaluating pulmonary surfactant. F Appl Physiol 1977;43:198-203.

24 Lewis JF, Jobe AH. Surfactant and the adult respiratory distress syndrome. Am Rev Respir Dis 1993;147:218-33.

25 Girod S, Galabert C, Lecuire A, Zahm JM, Puchelle E. Phospholipid composition and surface-active propertie of tracheobronchial secretions from patients with cystic fibrosis and chronic obstructive pulmonary diseases. Pediatr Pulmonol 1992;13:22-7.

26 Doyle IR, Barr HA, Davidson KG, Nicholas TE. Differential changes in SP-A and disaturated phospholipids in the isolated perfused rat lung and in vivo. Am f Physiol 1996; 271:L374-82.

27 Hamm H, Fabel H, Bartsch W. The surfactant system of the adult lung: physiology and clinical perspectives. Clin the adult lung: physiolo

28 Van Iwaarden F, Welmers B, Verhoef J, Haagsman HP, van Golde LMG. Pulmonary surfactant protein A enhances the host-defense mechanism of rat alveolar macrophages. Am 7 Respir Cell Mol Biol 1990;2:91-8.

29 Mander A, Hockey PM, Wang YJ, Postle AD. Pulmonary surfactant composition of bronchoalveolar lavage (BAL) fluid from children with cystic fibrosis. Eur Respir f 1996 9(Suppl 23):P1160. 